\title{
Tingkat Pengetahuan dan Sikap Pelajar di SMK Kerabat Kita Bumiayu Mengenai Kasus Penyalahgunaan Obat Dengan Metode Peer Education Sebagai Upaya Apoteker Dalam Promosi Kesehatan
}

\author{
Radesty Citra Agmalia ${ }^{*}$, Peppy Octaviani DM¹, Sunarti ${ }^{1}$ \\ ${ }^{1}$ Universitas Harapan Bangsa Purwokerto, Indonesia \\ *corresponding author \\ Email: radesty2014@gmail.com
}

Diterima : 29 September 2021

Direvisi : 12 Oktober 2021

Publikasi : 20 Oktober 2021

doi:10.52216/jfsi.vol4no2p85-90

\begin{abstract}
Drug abuse is estimated to affect 35 million people globally and requires treatment. Seeing the magnitude of the influence of group membership for adolescents, a health promotion strategy with the right method is needed, so that the information received can increase students' knowledge and attitudes regarding drug abuse cases. The purpose of this study was to determine the effect of the peer education method on the level of knowledge and attitudes of students regarding drug abuse cases. This type of research is descriptive with a cross sectional approach. The population in this study are students SMK Kerabat Kita Bumiayu. The research sample was 94 respondents. The research instrument used was a questionnaire. Conclusions based on univariate analysis, the majority of students there are 68 male (72.3\%), female students 26 (27.7\%) and students living with parents 54 (57.4\%) the status of living in boarding houses is $37(39.4 \%)$ and the status of living with parents is $3(3.2 \%)$. The results showed that the peer education method had an effect on students' knowledge and attitudes regarding drug abuse cases $(P=0.0000)$. In conclusion, there is an influence of the peer education method on the knowledge and attitudes of students at SMK Kerabat Kita Bumiayu.
\end{abstract}

Keywords: Peer Education Method, Knowledge, Drug abuse, Attitude

\section{Intisari}

Penyalahgunaan NAPZA diperkirakan secara global dialami 35 juta orang dan membutuhkan pengobatan. Melihat besarnya pengaruh membership group bagi remaja, maka diperlukan strategi promosi kesehatan dengan metode yang tepat, sehingga informasi yang diterima dapat meningkatkan pengetahuan dan sikap pelajar mengenai kasus penyalahgunaan obat. Tujuan penelitian ini adalah untuk mengetahui adanya pengaruh metode peer education terhadap tingkat pengetahuan dan sikap pelajar mengenai kasus penyalahgunaan obat. Jenis penelitian ini yaitu deskriptif dengan pendekatan cross sectional. Populasi dalam penelitian ini yaitu pelajar SMK Kerabat Kita Bumiayu. Sampel penelitian sebanyak 94 responden. Instrumen penelitian yang digunakan adalah kuesioner. Kesimpulan berdasarkan analisis univariate, pelajar di sana mayoritas berjenis kelamin laki-laki sebanyak 68 (72,3 $\%)$, pelajar perempuan sebanyak $26(27,7 \%)$ dan pelajar yang berstatus tempat tinggal bersama orang tua sebanyak 54 (57,4\%), berstatus tinggal kost sebanyak 37 (39,4\%) dan berstatus tinggal bersama orang tua 3 (3,2\%). Hasil penelitian menunjukkan bahwa adanya pengaruh metode peer education terhadap pengetahuan dan sikap pelajar mengenai kasus penyalahgunaan obat $(P=0,0000)$. Kesimpulannya adanya pengaruh metode peer education terhadap pengetahuan dan sikap pelajar di SMK Kerabat Kita Bumiayu. 


\section{Pendahuluan}

Penyalahgunaan NAPZA diperkirakan secara global dialami 35 juta orang dan membutuhkan pengobatan (UNODC, 2019). Data pidana narkoba yang didapatkan dari tahun 2007-2011 (dalam BNN, 2012) menunjukkan bahwa jumlah tertinggi tersangka kasus narkoba di Indonesia khususnya di Provinsi Jawa Tengah berada pada jenjang pendidikan SMA/SMK. Persentase pengguna NAPZA pada tingkat ini di Indonesia yaitu sebesar $61,9 \%$ dengan jumlah total kasus sebanyak 117.147 orang (Firdaus dan Hidayati, 2018).

Berdasarkan hasil wawancara oleh kepala Badan Narkotika Kabupaten Brebes Atmo Tan Sidik dalam berita online Tribunjateng (2016) bahwa penyalahgunaan NAPZA ataupun obatobatan terlarang di Brebes paling banyak dikonsumsi kalangan pelajar rata-rata di usia belasan hingga 25 tahun. Menurutnya, hal ini dikarenakan jalur pantura Brebes merupakan jalur perlintasan narkotika baik jenis sabu-sabu, ekstasi maupun narkotika jenis lainnya. Hal itu lantaran posisi kota Bawang yang berada di jalur perbatasan Jawa Tengah - Jawa Barat.

Melihat besarnya pengaruh membership group bagi remaja, oleh karena itu perlu dilakukan upaya promkes (promosi kesehatan) dengan metode yang tepat, sehingga informasi yang diterima dapat meningkatkan pengetahuan dan sikap pelajar mengenai kasus penyalahgunaan obat. Salah satunya adalah metode peer education. Peer education adalah upaya kegiatan pembelajaran dalam pengembangan pengetahuan, sikap dan tindakan seseorang yang berlangsung di antara teman sebaya (Pranawa et al., 2018). Selain itu diperlukan juga sarana promosi kesehatan yaitu apoteker.

Berdasarkan manfaat yang dapat diberikan dari pemberian pembelajaran kesehatan dengan metode peer education terhadap pengetahuan dan sikap remaja, maka peneliti tertarik untuk melakukan penelitian mengenai "Tingkat Pengetahuan dan Sikap Pelajar di SMK Kerabat Kita Bumiayu Mengenai Kasus Penyalahgunaan
Obat dengan Metode Peer Education sebagai Upaya Apoteker dalam Promosi Kesehatan".

\section{Metode Penelitian}

\subsection{Rancangan Penelitian}

Metode penelitian ini yaitu deskriptif dengan pendekatan cross sectional. penelitian ini dilakukan di SMK Kerabat Kita Bumiayu pada bulan Maret sampai April 2021. Populasi dalam penelitian ini yaitu pelajar di SMK Kerabat Kita Bumiayu dengan jumlah responden 94 pelajar diambil berdasarkan perhitungan rumus slovin. Pengambilan sampel penelitian diambil dengan metode sampling insidental yang berdasarkan kriteria inklusi dan eksklusi.

\subsection{Analisis Data}

Analisis univariat secara deskriptif karakteristik sampel yaitu berdasarkan jenis kelamin dan status tempat tinggal. Analisis bivariat pada kategori pada uji Chi-Square menggunakan aplikasi SPSS. Dalam data apabila $\mathrm{p}<0,05$ maka adanya hubungan yang signifikan antara kedua variabel yang diteliti dan apabila p>0,005 maka tidak ada hubungan yang signifikan antara kedua variabel yang diteliti.

\section{Hasil dan Pembahasan}

Tabel 1. Karakteristik Responden

\begin{tabular}{lcc}
\multicolumn{1}{c}{ Karakteristik } & N & \% \\
\hline Jenis Kelamin & & \\
Laki - laki & 68 & 72,3 \\
Perempuan & 26 & 27,7 \\
\hline Status Tempat tinggal & & \\
Bersama orang tua & 54 & 57,4 \\
Kost & 37 & 39,4 \\
Bersama saudara & 3 & 3,2 \\
\hline
\end{tabular}

Hasil yang diperoleh dari distribusi karakteristik jenis kelamin sebagian besar yaitu berjenis kelamin laki-laki sebanyak 68 pelajar dengan persentase $(72,3 \%)$ dan untuk responden dengan jenis kelamin perempuan sebanyak 26 pelajar dengan persentase $(27,7 \%)$. Penelitian ini sesuai dengan hasil survei BNN tahun 2016 yang menyatakan bahwa jenis kelamin laki-laki lebih 
berisiko menggunakan narkoba dibandingkan dengan jenis kelamin perempuan.

Didukung oleh hasil penelitian Priescisila dan Mahmudah (2017), yang mengatakan bahwa hasil penggunaan trihexyphenidryl sebagian besar berjenis kelamin laki-laki. Remaja yang berjenis kelamin laki-laki cenderung mengalami perubahan ke arah negatif. Hal ini disebabkan karena orang tua menganggap anak laki-laki lebih mandiri dan bisa menjaga diri dilingkungan luar dibandingkan perempuan sehingga laki-laki lebih bebas berinteraksi.

Berdasarkan hasil yang diperoleh dari distribusi karakteristik status tempat tinggal responden yang tinggal bersama orang tua sebanyak 54 pelajar dengan persentase $(57,4 \%)$. Bertempat tinggal di kos sebanyak 37 pelajar dengan persentase $(39,4 \%)$. Bertempat tinggal bersama saudara yaitu sebanyak 3 pelajar dengan persentase $(3,2 \%)$.

Tekanan yang dirasakan pelajar itu sendiri bisa mengarah ke hal negatif oleh sebab itu pelajar mencari ketenangan dengan cara menyalahgunakan obat. Cara bergaul mereka dapat juga memberikan efek yang negatif pada diri sendiri terutama lingkungan yang berada di luar rumah karena pelajar lebih banyak berada di luar rumah menghabiskan waktu. Selain itu, lingkungan rumah (orang tua) terlalu sibuk dapat menyebabkan anak merasa kurang perhatian. Keadaan ini merupakan salah satu yang menyebabkan anak lebih cenderung bergaul dengan lingkungan luar rumah dibandingkan dengan keluarga sendiri (Nur'artavia, 2017). Lingkungan keluarga yang mengekang atau otoriter cenderung kurang bahagia, mudah tersinggung dan tidak bersahabat (Lestari, 2012).

\subsection{Tingkat Pengetahuan Responden}

Pengetahuan merupakan aspek penting dalam membentuk tindakan seseorang. Tingkat pengetahuan responden diketahui menggunakan instrumen yang dibagikan kepada responden dengan pengisian kuesioner sebelum maupun sesudah (pre-test dan post-test) diberikannya edukasi oleh edukator dengan menggunakan metode peer educator pada responden.

Berdasarkan tabel 4.6 skor pre-test dan posttest yang diperoleh dari tingkat pengetahuan responden mengenai kasus penyalahgunaan obat menunjukkan adanya peningkatan yaitu sebesar $14,9 \%$ setelah diberikan edukasi. Persentase skor pre-test yang masuk ke dalam kategori baik yaitu sebesar 28,7\% meningkat menjadi 43,6 \% pada saat post-test.

Tabel 2. Persentase hasil pre-tes dan post-test tingkat pengetahuan responden

\begin{tabular}{|c|c|c|}
\hline Kategori & Pre-test & Post-test \\
\hline Baik & $27(28,7 \%)$ & $41(43,6 \%)$ \\
\hline Cukup & $55(58,5 \%)$ & $45(47,9 \%)$ \\
\hline Kurang & $12(12,8 \%)$ & $8(8,5 \%)$ \\
\hline Total & $94(100,0 \%)$ & $94(100,0 \%)$ \\
\hline
\end{tabular}

Berdasarkan hasil pre-test dan post-test yang didapat dalam penelitian ini menunjukkan bahwa adanya perbedaan pengetahuan sebelum dan sesudah diberikannya intervensi edukasi yang artinya pengetahuan dapat dipelajari dengan adanya pembelajaran atau edukasi yang diberikan oleh kelompok sebayanya.

Meningkatnya pengetahuan responden merupakan hasil keingintahuan yang terjadi setelah proses pengindraan. Dan menurut Sulistiyana dan Irawan (2014) pengetahuan pada masyarakat salah satunya dipengaruhi oleh pendidikan, informasi, pengalaman, minat. Dari tabel tersebut yaitu pengetahuan responden meningkat karena adanya rasa ingin tahu dari responden untuk melihat serta mendengarkan edukator dalam menyampaikan materi dan ketika proses diskusi tanya jawab, hal ini merupakan pengindraan yang dilakukan responden untuk meningkatkan pengetahuannya (Notoatmodjo, 2012). Hasil penelitian yang dilakukan oleh Hidayati dan Indarwati (2012) yaitu pengetahuan tinggi pada pelajar, membuat mereka memiliki perlindungan diri untuk mencegah hal yang tidak baik terhadap penyalahgunaan obat dibandingkan dengan kurangnya pengetahuan.

Tabel 3. Uji chi-square pre-test dan post-test pengetahuan responden

\begin{tabular}{lcccc}
\hline \multirow{2}{*}{ Pre-test } & \multicolumn{3}{c}{ Post-test } & P value \\
\cline { 2 - 5 } Baik & Baik & Cukup & Kurang \\
& 22 & 5 & 0 & \\
Cukup & $(23,4 \%)$ & $(5,3 \%)$ & $(0,0 \%)$ & \\
& 19 & 34 & 2 & \\
& $(20,2$ & $(36,2 \%)$ & $(2,1 \%)$ & \\
Kurang & $\%)$ & & & 0,000 \\
& 0 & 6 & 6 & \\
Total & $(0,0 \%)$ & $(6,4 \%)$ & $(6,4 \%)$ & \\
& 41 & 45 & 8 & \\
& $(43,6$ & $(47,9 \%)$ & $(8,5 \%)$ & \\
\hline
\end{tabular}


Berdasarkan hasil uji chi-square pada $\alpha$ 5\% dengan derajat kepercayaan 95\% menunjukkan bahwa adanya hubungan yang signifikan pengaruh positif pada pendidikan kesehatan dengan metode peer education terhadap pengetahuan pelajar tentang penyalahgunaan obat yang dibuktikan dengan nilai $p=0,000$. Hal ini menunjukkan bahwa pengetahuan pelajar mengenai penyalahgunaan obat meningkat setelah diberikan perlakuan pendidikan kesehatan dengan metode peer education.

Konsep pendidikan sebaya menurut Imron (2012) merupakan pemberian informasi dengan menggunakan bahasa yang kurang lebih sama sehingga informasi yang diperoleh dapat mudah dipahami oleh teman sebayanya. Hal ini membuat pengetahuan remaja mengenai penyalahgunaan obat dapat lebih banyak diperoleh. Peer education dapat meningkatkan pengetahuan remaja secara efektif karena situasi berdiskusi yang terbuka di kalangan remaja mendukung terhadap pembicaraan dan tanya jawab menjadi lebih luas dan menyenangkan tanpa adanya ketegangan (Astari dan Fitriyani, 2019).

Kunci dari keterbukaan dan kebebasan perlu menjadi kegiatan pendidikan kesehatan bagi kalangan remaja. Jika edukator orang dewasa akan dapat menimbulkan kesenjangan dalam menggunakan bahasa penyampaian, istilah dan gaya bicara yang dapat menghambat pemahaman arti pesan yang disampaikan dan akan menimbulkan kondisi belajar yang kurang interaktif (Hasbi, 2019).

\subsection{Sikap Responden}

Sikap responden diketahui setelah dilakukannya pengukuran menggunakan kuesioner sebelum dan sesudah diberikannya intervensi edukasi pada responden. Sikap yaitu wujud kesiapan individu untuk bereaksi terhadap objek di lingkungan tertentu dan belum merupakan tindakan atau aktivitas akan tetapi predisposisi terjadinya suatu tindakan atau perilaku (Notoatmodjo, 2012).

Tabel 4. Persentase hasil pre-test dan post-test sikap responden

\begin{tabular}{lcc}
\hline Kategori & Pre-test & Post-test \\
\hline Baik & $27(28,7 \%)$ & $53(56,4 \%)$ \\
cukup & $48(51,1 \%)$ & $37(39,4 \%)$ \\
Kurang & $19(20,2 \%)$ & $4(4,3 \%)$ \\
\hline Total & $94(100,0 \%)$ & $94(100,0 \%)$ \\
\hline
\end{tabular}

Agmalia, Oktober 2021
Berdasarkan tabel 4.9 hasil skor pre-test dan post-test mengenai sikap responden dalam kasus penyalahgunaan obat menunjukkan peningkatan yaitu $27,7 \%$ setelah diberikannya edukasi. Hasil persentase skor pre-test yang masuk ke dalam kategori baik sebesar 28,7\% yang kemudian meningkat menjadi $56,4 \%$ pada skor post-test. Hasil penelitian ini menunjukkan peningkatan sikap responden yang semakin baik mengenai topik penyalahgunaan obat. Hal itu semakin terlihat jelas dengan adanya data yang memiliki tingkat sikap dengan kategori kurang menurun yaitu $20,2 \%$ menjadi $4,3 \%$.

Bukti adanya peningkatan sikap yang semakin baik dikarenakan responden dapat memberikan tanggapan yang positif dan sudah cukup memahami permasalahan penyalahgunaan obat. Oleh sebab itu pengetahuan pelajar meningkat akan melahirkan suatu sikap yang baik pula. Meskipun perubahan sikap tidak drastis terjadi pada saat itu juga, karena metode peer education hanya sebuah wadah atau perantara sarana yang digunakan agar terjadi proses atau progres seseorang ke arah yang lebih baik sehingga perubahan itu akan terjadi pada hari-hari yang akan datang bisa positif maupun negatif (Astari dan Fitriyani, 2019).

Tabel 5. Uji chi-square pre-test dan post-test sikap responden

\begin{tabular}{lcccc}
\hline \multirow{2}{*}{ Pre-test } & \multicolumn{3}{c}{ Post-test } & P value \\
\cline { 2 - 5 } Baik & Baik & Cukup & Kurang & \\
\multirow{4}{*}{ Cukup } & 27 & 0 & 0 & \\
& $(28,7 \%)$ & $(0,0 \%)$ & $(0,0 \%)$ & \\
Kurang & 19 & 27 & 2 & \\
& $(20,2 \%)$ & $(28,7 \%)$ & $(2,1 \%)$ & 0,000 \\
Total & $(7,4 \%)$ & 10 & 2 & \\
& 53 & $(10,6 \%)$ & $(2,1 \%)$ & \\
& $(56,4 \%)$ & $(39,4 \%)$ & $(4,3 \%)$ & \\
\hline
\end{tabular}

Berdasarkan hasil uji chi-square pada $\alpha 5 \%$ dengan derajat kepercayaan 95\% menunjukkan bahwa adanya hubungan yang signifikan pengaruh positif pada pendidikan kesehatan metode peer education terhadap sikap dalam kasus penyalahgunaan obat yang dibuktikan dengan nilai $p=0,000$. Hal ini menunjukkan bahwa sikap responden terkait penyalahgunaan obat meningkat setelah diberikan perlakuan pendidikan kesehatan dengan metode peer education. Penelitian ini membuktikan bahwa metode peer education telah 
efektif dapat meningkatkan sikap responden mengenai penyalahgunaan obat.

Pelaksanaan dan evaluasi peer education mendukung program disekolah untuk mencegah dan mengurangi risiko tinggi kasus penyalahgunaan obat di kalangan remaja khususnya pelajar. sikap seseorang tidak dapat berubah begitu saja tanpa ada proses yang mendasarinya. Melalui peer education akan terjadi proses perubahan cara berpikir seseorang karena adanya diskusi terbuka untuk mengeluarkan pendapat. Salah satu faktor perubahan sikap adalah pengetahuan dan kepercayaan yang didapat dari hasil pengindraan salah satunya didapat saat proses belajar (Dalimunthe et al., 2016).

Penelitian Nurmala et al., (2020) mengenai pendidikan teman sebaya (peer education) untuk mencegah penggunaan narkoba menunjukkan metode peer education memiliki efek lebih besar dalam mempromosikan kesehatan remaja melalui peningkatan pengetahuan, sikap, perilaku kesehatan dan kemanjuran diri dibandingkan dengan metode lain seperti ceramah. Remaja bersedia menerima bimbingan dari teman sebayanya dibandingkan orang dewasa di lingkungan sosial atau sekolah mereka. Metode peer education sangat efektif dalam mencegah penggunaan narkoba di kalangan pelajar (Hasel et al., 2016).

\section{Kesimpulan}

Berdasarkan hasil penelitian diketahui bahwa sebagian besar responden berjenis kelamin lakilaki yaitu $72,3 \%$ dan responden berjenis kelamin perempuan yaitu $27,7 \%$.

Tingkat pengetahuan responden mengenai kasus penyalahgunaan obat meningkat signifikan yaitu $28,7 \%$ menjadi $43,6 \%$. Pengetahuan tersebut meningkat sebanyak $14,9 \%$ yang masuk ke dalam kategori baik.

Sikap responden mengenai kasus penyalahgunaan obat meningkat signifikan yaitu $28,7 \%$ menjadi $56,4 \%$. Sikap tersebut meningkat sebanyak $27,7 \%$ yang masuk ke dalam kategori baik.

Pemberian edukasi dengan menggunakan metode peer education dapat meningkatkan pengetahuan dan sikap pelajar di SMK Kerabat Kita Bumiayu mengenai penyalahgunaan obat.
Adanya pengaruh pendidikan kesehatan metode peer education terhadap pengetahuan dan sikap pelajar secara statistik dibuktikan dari hasil uji chi-square yaitu nilai $p=0,000$.

\section{Daftar Pustaka}

Astari, R. yuni and Fitriyani, E. (2019) 'Pengaruh Peer Education Terhadap Pengetahuan Dan Sikap Remaja Tentang Pencegahan Hiv-Aids Di Smk Korpri Majalengka', Jurnal Ilmu Kesehatan Bhakti Husada: Health Sciences Journal, 10(2), pp. 150-159. doi: 10.34305/jikbh.v10i2.93.

Dalimunthe, E. M., Lubis, N. L. and Tukiman (2016) 'Efektivitas Pelatihan Pendidik Sebaya (Peer Group) Terhadap Pengetahuan Dan Sikap Siswa Sma N 1 Padangsidimpuan Tentang Pencegahan Napza Di Kota Padangsidimpuan Tahun 2016', Jurnal Kesehatan Ilmiah Indonesia, 1(1), pp. 43-50.

Firdaus, A. M. Y. and Hidayati, E. (2018) 'Pengetahuan dan Sikap Remaja terhadao Penggunaan NAPZA di Sekolah Menengah Atas di Kota Semarang', Jurnal Keperawatan, 6(1).

Hasbi, M. (2019) 'Analisis Model Peer Education Metode Adolescent Friendly Terhadap Peningkatan Pengetahuan Dan Sikap Remaja Tentang Perilaku Seksual Berisiko', JURNAL KEPERAWATAN TERPADU (Integrated Nursing Journal), 1 no 1(1), pp. 29-37.

Hasel, K. M. et al. (2016) 'Effectiveness of peerled media education program for drug prevention among students', European Journal of Forensic Sciences, 3(3). doi: 10.5455/ejfs.206362.

Hidayati, P. E. and Indarwati (2012) 'Gambaran Pengetahuan dan Upaya Pencegahan Terhadap Penyalahgunaan Narkoba pada Remaja di SMK Negeri 2 Sragen Kabupaten Sragen', GASTER, 9(1), pp. 15-21. Available at: http://www.jurnal.stikesaisyiyah.ac.id/index.php/gaster/article/view/3 $0 / 27$.

Lestari, S. (2012) Psikologi Keluarga. jakarta: Prenada Media Group. 
Nurmala, I. et al. (2020) 'Peer-to-peer education to prevent drug use : A qualitative analysis of the perspectives of student peer educators from Surabaya, Indonesia', Health Promot Journal of Australia, pp. 1-6. doi: 10.1002/hpja.400.

Imron, A. (2012) Pendidikan Kesehatan Reproduksi Remaja: Peer Education dan Efektivitas Program KIR-KRR di Sekolah. 2nd edn. Yogyakarta: Ar Ruzz.

Notoatmodjo (2012) Metodologi Penelitian Kesehatan. Jakarta: PT Rineka Cipta.

Nur'artavia, M. R. (2017) 'Karakteristik Pelajar Penyalahguna Napza Dan Jenis Napza Yang Digunakan Di Kota Surabaya', The Indonesian Journal of Public Health, 12(1), p. 27. doi: 10.20473/ijph.v12i1.2017.27-38.

Pranawa, S., Yuliani, S. and Humsona, R. (2018) 'Memanfaatkan Peer Education Strategy Tentang Bahaya Penyalahgunaan Narkoba', Jurnal SNIEMAS UAD, pp. 279-286.

Priescisila, I. R. and Mahmudah (2017) 'Hubungan Faktor Lingkungan dengan Penggunaan Trihexyphenidyl pada Remaja di BNN Kota Surabaya', Jurnal Biometrika dan Kependudukan, 5(1), pp. 70-79. doi: 10.20473/jbk.v5i1.2016.70-79.

Sugiyono (2018) Metode Penelitian Kuantitatif, Kualitatif, dan Kombinasi (mixed Methods). 10th edn. Bandung: Alvabeta.

Sulistiyana, C.S., Irawan, Y. (2014) 'Hubungan pengetahuan masyarakat tentang obat anti nyeri terhadap pengobatan sendiri pada nyeri akut (Studi di Kelurahan Wadowetan Kecamatan Bantarujeg Majalengka', Jurnal Kedokteran dan Kesehatan, 1(2), pp. 1-5.

UNODC. World Drug Report 2019: 35 million people worldwide suffer from drug use disorders while only 1 in 7 people receive treatment.

https://www.unodc.org/unodc/en/frontpage/2 019/June/world-drug-report-2019_-35million-people-worldwide-suffer-from-druguse-disorders-while-only-1-in-7-peoplereceive-treatment.html. diakses tanggal 05 Desember 2020. 